\title{
The Consequences of Corporate Governance, Audit Fee Contract, and Financial Bankruptcy on Auditor Change in Banking Sector
}

\author{
Dien Noviany Rahmatika ${ }^{1}$, Maulida Dwi Kartikasari ${ }^{2}$ \\ Universitas Pancasakti Tegal Jl Halmahera KM 1 Tegal ${ }^{1,2}$ \\ \{diennovi@upstegal.ac.id¹, maulidadwikartikasari@upstegal.ac.id²\}
}

\begin{abstract}
This study aims to determine the consequences of orporate governance, audit fees contract, and financial bankruptcy on auditor change in banking sector. This research use 4 indicators of good corporate governance mechanism. Those indicators are managerial ownership, institusional ownership, audit comittee, and board of commisioner. This study uses a sample of banking companies listed on the Indonesia Stock Exchange during the 20162019 period. The number of banking companies sampled in this study were 21 companies with 4 years of observation. Based on the purposive sampling method, the total sample of research is 84 financial statements. To test the by using logistic regression analysis. The results of this study indicate that there is no impact of managerial ownership, institutional ownership, composition of the board of commissioners, audit committee, and audit fees contract on auditor change. However, audit fee contract has an positive impact on auditor change.
\end{abstract}

Keywords: corporate governance, fee contracts, financial bankruptcy, auditor change

\section{Introduction}

To arrange the financial statements, it is necessary han an independent teams to evaluate the financial statements well. Public accountants and auditor are independent parties that able to make an assessment of relevance and reliability of the company's. Financial reports must go trough an audit process carried out by an independent audience, which begins with an examination of the financial statements to obtain and evaluate evidence related to the company's financial statements. Auditor independence is the main key to assesing the fainess of financial statements. In 2018 there were cases involving the auditor and his client, namely PT Sunprima Nusantara Financing and the Public Auditors, Marlinna and Marliyana Public Accounting Firm. It begins from a public accountant who examined the financial statements of PT SNP and gave an unqualified opinion. This is different from the results of the examination by the Ooritas Jasa Keuangan which found that were not in accordance with the actual financial condition. finnaly sanction given by Pusat pembinaan profesi keuangan (PPPK) in the form of administrative sanction which were valid for 12 months (Wareza, 2018).

From the case that ocure, it is feared that the understanding of audit services for a long period that can threaten the independence of auditors. One way to minimize the emergence of 
cases regarding long audit engagement is by doing auditor rotation or auditor change. Fairness of the financial statements performed by auditors is closely related to one of the internal factors of corporate governance. Good corporate governance is very effective in preventing irregularities in financial statementes. Based on Peranian and Mimbas's (2018) research has no effect on auditor change, however, Johari (2015) showed that the variavle of good corporate governance mechanism has an effect on auditor change.

Change of KAP usually increase in audit fees because when the auditor first performs audit services, usually what is done is understanding the company's environment and the audit risk. It is not easy to do it. So, sometimes client sould be able to pay more. To avoid the negative impact, management is necessary to be careful for consideration and planning before change the auditor. Karliana and Resmiyati (2017) found that audit fees not affect to company's decision to do auditor change. . It can be concluded that if the audit fee is high then it may not necessarily affect the company to do auditor switching, because company assumes that the auditor or KAP used so far have known and understand about the condition of the company (Wea and Murdiawati, 2015). The company thinks that the auditor or KAP has been on duty so far competent in carrying out their duties and are satisfied with the audit results given, so the company is considering do auditor switching even though the fees are offered by the auditor or the KAP tends to be high, the company perceives things is in accordance with the work given by auditors and KAP who are currently on duty. The results of this study are supported by research conducted by Nasir (2018) which states that the audit fee has a negative effect on auditor switching.

Financial bankruptcy is a liquidity problem that will have severe consequences and cannot be resolved without a change in the size of the company's operations or structure (Aroh et al, 2018). If the company's condition is in financial distress, the company tends not to do auditor switching. This is because auditor changes that occur too often in companies can increase audit fees. When the auditor first audits a client, the first thing to do is to understand the client's business environment and the client's audit risk that will occur, so that it will have an impact on the increase in audit fees. The indicator of financial distress is when the company is unable to fulfill its financial obligations and the company stops its workforce. Financial bankruptcy is a condition when a company experiencing financial difficulties. This condition is where the company is unable to fulfill the obligation and allows for bankruptcy. Farida (2016), Inawati (2018) showed there was no effect between financial bankruptcy and auditor change. Meanwhile ramantha (2014) found an influence between financial bankruptcy on auditor change.

\section{Literature Review}

Agency Theory developed by jensen and Meckling (1976) which describes the agency relationship, namely between principal (shareholders) and the agent (management) which is bound by a contract, is detemined by both of them where the principal uses an agent to deliver services that are of interest to the principal. The action taken is to present a third party, namely auditor to mediate between the interests of the principal and the agent in managing the company's finances. Auditor change is a replacement for Public Accounting Firm or a Public Accountant by a company. According to Udayanti and Ariyanto (2017) companies in changing auditors can be caused by government regulations (mandatory) and changing auditors at the will of the company itself (voluntary). There are two factors that outline the background for auditor change. These factors come from within the company itself (internal) 
which is commonly referred to as client factors, as well as factors from outside the company (external). Compulsory voluntary replacement of auditors can be distinguished on the basis of which party is the focus of attention from the issue of auditor independence. If the change of auditors is voluntary, the main concern is on the client side. Conversely, if the change occurs compulsorily, the main attention turns to the auditors (Febrianto, 2009).

Good Corporate Governance is a set of regulations governing the relationship between shareholders, managers (managers), creditors, government, employees and other internal and external stakeholders related to their rights and obligations or in other words a system that regulates and controlling the company (FCGI, 2002). Good corporate governance can also be defined as a form of mechanism and by which company processes are carried out. According to Samanta \& Das, (2011). At the most basic level, good corporate governance is a process whereby a company tries to minimize transaction costs and aggression costs associated with business costs carried out by the company.

Good corporate governance is very good for company growth. Good management can certainly solve various problems that exist within the company. Good corporate governance can also be used as an effort to prevent fraud between stakeholders in the company. The cost of funding in the company can also be influenced by good corporate governance, to achieve the optimal level must minimize the cost of capital. This can all be achieved with good teamwork and individual awareness. In practice, good corporate governance consists of several influential elements. This study will only discuss elements of corporate governance, namely managerial ownership, ownership concentration, the composition of the board of commissioners and the audit committee which are the focus on the variable of good corporate governance mechanisms.

The Audit Fee is the amount to be paid by the company as a form of reward for the work done by the auditor (Dwijayanti et.al, 2014). According to Agoes (2012), audit fees are the amount of fees depending on the auditor's assignment, the complexity of the services provided, the level of expertise required to carry out these services, the cost structure of the KAP concerned and other professional considerations. The audit fee is determined when there is a contract between the auditor and his client based on an agreement, usually determined before starting the auditing process. According to Sya'diyah and Ridwan (2015), the audit fee is a form of honorarium charged by a public accountant to an audit company for audit services performed by a public accountant on financial statements.

Financial bankruptcy is a stage of decline in the financial condition of the company's operating cash flow that is unable to meet current liabilities. At maturity that will lead to the bankruptcy of the Ashari company, (2018). Financial bankruptcy is a liquidity problem that will have severe consequences and cannot be resolved without a change in the size of the company's operations or structure. Information about financial distress can be used as an early warning of company bankruptcy so that company management can take quick action to prevent problems before bankruptcy (Ismanto \& Manda, 2018). Financial distress is the condition of a company that is experiencing financial difficulties, a company that is experiencing financial distress tends to move auditors or auditor change.

\section{Conceptual Framework and Hyphotesis}

Managers who own company shares align their interests with those of shareholders. Managerial ownership is considered as an important company ownership structure. The increasing of managerial share ownership the better the company performance. According to 
Imanta and Satwiko (2011), with managerial ownership, managers as the party operating the company as well as shareholders, will be motivated to act in line with the wishes of shareholders by increasing performance and responsibility in achieving prosperity for shareholders. Managers will experience firsthand the benefits of the decisions they make and the harm they will receive when making wrong decisions. According to Johari, (2015) in his research states that auditor change occurs because the previous auditor cannot be in line with the interests of company management.

H1: Managerial ownership has an effect of auditor change. Institutional Ownership is the number of shareholders or the percentage of share ownership other than public ownership in the share ownership structure. The higher the level of institutional ownership, the weaker internal corporate governance mechanisms and the more unclear the benefits will be. Therefore, companies with large controlling owners are more likely to switch or switch to audit firms that are more flexible and in accordance with the wishes of company management. According to Permanasari (2010), institutional ownership is ownership of company shares owned by institutions or institutions established in Indonesia such as insurance companies, banks, investment companies and other institutional ownership. Institutional shareholders who have large shareholdings have an intensive monitoring of corporate decision making and can affect company performance. So that the existence of large share ownership by institutional investors will encourage the influence of the composition of the independent board of commissioners on auditor change. Lin and Liu (2009) state that the desire to maximize selfinterest through tunneling in companies that go public is to avoid being monitored by highquality audit companies. The higher the level of concentrated ownership, the weaker internal corporate governance mechanisms and the more unclear the benefits will be.

H2: Institusional ownership has an effect of auditor change. Johari (2015) found that the composition of independent commissioners on the total number of commissioners had a negative effect on the possibility of financial statement fraud, indicating that independent commissioners increased the ability of the board of commissioners as supervisors to properly carry out their supervisory functions. However, Chen and Zhou (2007) state that the composition of the independent commissioners affects the decision to change auditors by companies change to Big 4 accounting firms.

H3: independent commisioner has an effect auditor change. Audit Committee is the most important corporate governance mechanism with respect to auditing the company's financial statements, because the audit committee is responsible for hiring external auditors and overseeing audit quality. Responds to the theory that larger audit committees also allow attention to auditor reputation. According to Pierce and Zahra (1992) in Treskawati (2014) there is a significant negative relationship between the effectiveness of the audit committee and the dependence on resources if the company increases the resources of the audit committee members, it will also increase the performance of the company in dealing with problems faced by the company so that it can avoid company from financial trouble problems.

H4: board of committee has an effect oauditor change. Dwijayanti et al, (2014) The size of the determined audit fee illustrates the image of a public accounting firm in society, whether the auditor is a professional in his field or not. The higher the fee proposed by the company, the greater the opportunity for auditor change to occur because there is no agreement between the company and KAP regarding the amount of audit fees that will be received by the auditor. 
Lestari (2012). Agency theory aims to explain the principal's efforts to supervise the agent by presenting an independent third party. Supervision costs or monitoring costs are needed to be able to supervise agents. Costs are used by an organization or business to handle asymmetrical information and differences in objectives between management and shareholders. Therefore, this theory can be used to answer agency problems that occur because the parties working together have different goals (Hartadi, 2012). Auditors with high audit fees will encourage companies to switch to auditors with low fee fees. Auditors with high audit fees will also result in disagreements between the auditors and the company. Pradhana \& Suputra, (2015) argues that the company will change auditors if the fees offered are high and look for auditors with lower audit fees so as not to increase the company's burden. Wijaya \& Rasmini (2015) also has the same opinion that audit fees have a positive effect on auditor change. Payment of expensive audit fees in certain conditions will increasingly burden the company, so that the company will make changes to KAP, especially from Big Four KAP to non Big Four KAP. The price suitability factor is the main factor that causes client companies to change KAP.

H5: Contract fee has an effect auditor change. Financial bankruptcy is a stage of decreasing financial condition where the company's operating cash flow is not sufficient to pay off its current obligations at maturity which causes company bankruptcy (Ashari, 2018). Financial bankruptcy has an effect on changing auditors due to the decline in the company's financial capacity resulting in the company no longer having the ability to pay the audit fees charged by the Public Accounting Firm (Ismanto \& Manda, 2018). Companies that are experiencing financial bankruptcy will change auditors in the hope that the new auditors can provide an opinion that matches the company's expectations. The company also has the same characteristics, where when the company experiences financial bankruptcy, the management tends to save itself by looking for audiences who have high independence to maintain the management's reputation and the trust of the principal. In bad financial conditions, management when observing the auditor must choose an auditor with a fee that is not too large so that the company does not incur too large an audit fee. Andini et.al (2016) states that companies that have financial pressure tend to change auditors compared to their healthier peers, because client companies that are threatened with bankruptcy tend to increase the evaluation of subjectivity and auditor caution so that companies will tend to do auditor change. Yudha et.al (2018) and Harisman, (2017) also have the same opinion that financial bankruptcy has a positive effect on auditor change. Companies with financial bankruptcy conditions will replace their auditors with the premise that the new auditors are expected to provide better suggestions and responses that can improve the company's financial condition compared to the old auditors.

H6: Financial bankruptcy has an effect auditor change. From this description, we can conclude the following framework:

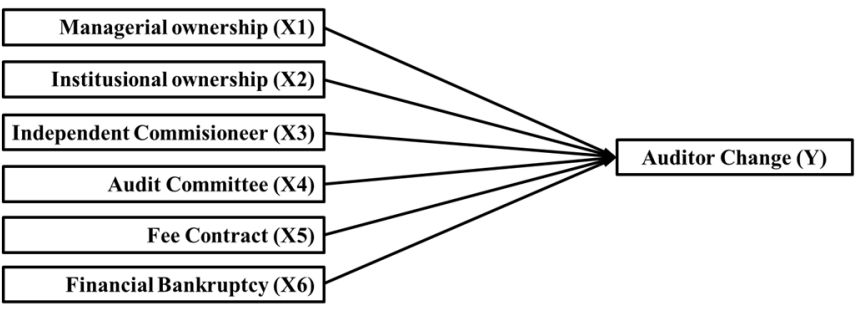

Fig. 1. Research Framework 


\section{Research Method}

This research using a quantitative research approach. Quantitative research is a method used to test a particular theory by examining the relationship between variables. According to (Sugiyono, 2017) quantitative research methods, namely research methods based on the philosophy of positivism, are used to research on certain populations or samples, data collection using research instruments, data analysis is quantitative or statistical, with the aim of testing predetermined hypotheses. The population used in this study were all 44 banking companies listed on the Indonesian Stock Exchange (BEI). The research period carried out for observation is from 2016-2019.

The study used a purposive sampling approach, according to (Sugiyono, 2017) purposive sampling is a sampling technique with certain considerations. The sample technique used in this study is the Non-probability sampling method according to Sugiyono (Sugiyono, 2017) Nonprobability sampling, which is a sampling technique that does not provide the same opportunity or opportunity for each element or member of the population to be selected as a sample.In this study the sample to be used must meet the sample criteria that have been determined in this study, namely as follows:

a. Banking companies listed on the Indonesia Stock Exchange period 2016-2019.

b. Banking companies listed on the Indonesia Stock Exchange that do not publish annual financial reports for the 2016-2019 period.

c. Banking companies listed on the Indonesia Stock Exchange that performed auditor change during the 2016-2019 period.

Operationalization of variables required to determine the types and indicators of the variables used in the study. In addition, this process is also intended to determine the measurement scale of each variable so that the hypothesis testing uses tools statistics can be done correctly.

Table 1. Operationalization of Variables

\begin{tabular}{|c|c|c|}
\hline Variable & Indicator & Scale \\
\hline \multirow{2}{*}{ Managerial ownership (X1) } & Number of shares owned by the manager & \multirow[b]{2}{*}{ Ratio } \\
\hline & 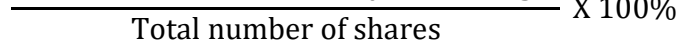 & \\
\hline Institusional ownership (X2) & $\frac{\text { Shares owned by institutions }}{\text { Total number of shares }} \times 100 \%$ & Ratio \\
\hline Independent Commisioneer (X3) & $\frac{\text { Shares owned by institutions }}{\text { Total board of commissioners }} \times 100 \%$ & Ratio \\
\hline Audit Committee (X4) & $\Sigma$ Number of audit committees & Ratio \\
\hline Fee Contract (X5) & $\begin{array}{l}\text { Clients using KAP affiliated with the } \\
\text { Big } 4 \text { are given code } 1 \text {, in addition to } 0 \\
\text { (dummy variable) }\end{array}$ & Nominal \\
\hline Financial Bankruptcy (X6) & $\mathrm{DER}=\frac{\text { Total debt }}{\text { Total Equity }} \times 100 \%$ & Ratio \\
\hline Auditor Change (Y) & $\begin{array}{c}\text { The client performs a KAP transfer given code } 1 \text {, } \\
\text { if not given code } 0 \text { (dummy variable) }\end{array}$ & Nominal \\
\hline
\end{tabular}


Testing of the hypothesis in this study was carried out using logistic regression, because according to Ghozali, (2018) this method is suitable for research where the dependent variable is categorical (nominal or non-metric) and the independent variable is a combination of metric and non-metric as well as in this research. Logistic regression does not need to assume data normality on the independent variables. The logistic regression model used in this study is as follows:

$\operatorname{Ln}(S 1-A S)=\alpha+\beta 1 \mathrm{KM}+\beta 2 \mathrm{KK}+\beta 3 \mathrm{DK}+\beta 4 \mathrm{KA}+\beta 1 \mathrm{FA}+\beta 2 \mathrm{FD}+\mathrm{e}$

Information :

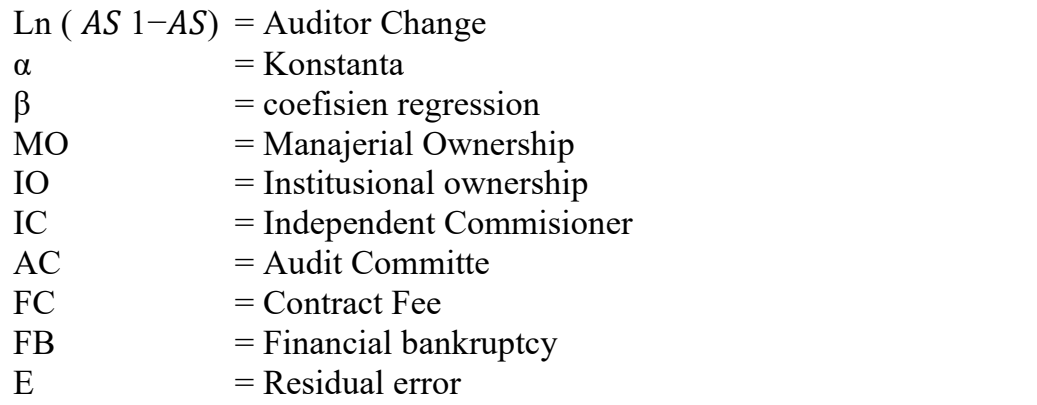

Descriptive Statistics aim to provide general information about the sample used in this study. General information on the data of this study uses the mean, minimum value, maximum value, and standard deviation.

Table 2. Statistic Descriptive

\begin{tabular}{lccccc}
\hline & N & Minimum & Maximum & Mean & Std. Deviation \\
\hline Auditor Change & 84 & 0 & 1 & .48 & .502 \\
Manajerial ownership & 84 & .00 & .10 & .0048 & .01807 \\
Institusional ownership & 84 & .00 & .99 & .6170 & .29301 \\
Independent Commisioner & 84 & .33 & .80 & .5724 & .10567 \\
Audit Committee & 84 & 3 & 7 & 4.07 & 1.095 \\
Fee contract & 84 & 0 & 1 & .71 & .454 \\
Financial bankruptcy & 84 & .41 & 14.75 & 5.4569 & 2.45107 \\
Valid N (listwise) & 84 & & & & \\
\hline
\end{tabular}

Source: Secondary data Prossesed (2020)

Logistic Regression Test. The first analysis conducted was to assess the feasibility of the logistic regression model to be used. The feasibility test of the logistic regression model was carried out using the Goddness of fit test as measured by the Chi-Square value at the bottom of the Hosmer and Lemeshow test.

Table 3. Hosmer and Lemeshow Test

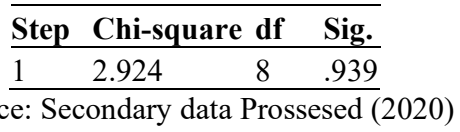

Table 3 shows the results of the Hosmer and Lemeshow test. With a significance probability showing the number 0.939 , the significance value obtained is greater than 0.05 , 
then $\mathrm{H} 0$ is accepted. This means that the regression model is suitable for use in further analysis, because there is no significant difference between the predicted classifications and the observed classifications.

The next step is to test the overall model (overall model fit). Testing is carried out by comparing the value between -2 Log Likelihood ( $-2 L L)$ at the beginning (Block Number $=0$ ) with the -2 Log Likelihood (-2LL) value at the end (Block Number $=1)$. There is a decrease in the value between the initial $-2 \mathrm{LL}$ function at the end (Block Number $=1$ ). The reduction in the value between the initial -2LL function and the -2LL value in the next step (final $-2 L L$ ) indicates that the hypothesized model is fit with the data (Ghozali, 2011).

Table 4. Overall Model Fit

\begin{tabular}{ccc}
\hline Iteration & $\mathbf{- 2}$ Log likelihood & Coefficients Constant \\
\hline \multirow{2}{*}{ Step 012} & 116.258 & -.095 \\
& 116.258 & -.095 \\
\hline \multicolumn{3}{r}{ Source: Secondary data Prossesed (2020) }
\end{tabular}

Based on the table, it is known that the $-2 \log$ Likelihood value in the Iteration History Block Number 0 is 116.258, which is greater than the -2Log Likelihood value of 64.756 in the Iteration History Block. Number 1. This decrease means a good regression. Next test is coefficient determination. he coefficient of determination is used to explain how much variability of the independent variables is able to explain the variability of the independent variables (Solikah, 2007). The coefficient of determination in the binary logistic regression is shown by the Nagelkerke R Square value. Nagelkerke R Square can be interpreted like the value of R Square in multiple regression (Ghozali, 2011).

Table 5. Coefficient Determination

\begin{tabular}{|c|c|c|c|c|}
\hline Step & -2 Log likelihood & Cox \& Snell R Square & Nagelkerke Square & $\mathbf{R}$ \\
\hline 1 & $65.427^{\mathrm{a}}$ & .454 & & .606 \\
\hline
\end{tabular}

Table 5 shows the value of the coefficient of determination in the logistic regression model indicated by the Nagelkerke R Square value. The Nagelkerke R Square value is 0.606 which means that the variability of the dependent variable that can be explained by the independent variable is $60.6 \%$, while the remaining $39.4 \%$ is explained by other variables outside the research model, such as managerial ownership, institutional ownership, composition of the board of commissioners, audit committee, contract fee, and financial bankruptcy. From testing the logistic regression equation, the logistic regression is obtained as follows:

$\operatorname{Ln}\left({ }_{1} A S\right)=21.245+-1.059 \mathrm{MO}+-1.166 \mathrm{OIO}+1.430 \mathrm{IC}+-0.300 \mathrm{AC}+-22.129 \mathrm{FC}+0.186 \mathrm{FB}$

(2)

Table 6. Coefficient Regression

\begin{tabular}{cccccccc}
\hline & & B & S.E. & Wald & df & Sig. & $\operatorname{Exp(B)}$ \\
\hline \multirow{5}{*}{ Step 1 $^{\text {a }}$} & MO & -1.059 & 72.857 & .000 & 1 & .988 & .347 \\
& IO & -1.166 & 1.257 & .861 & 1 & .354 & .311 \\
& IC & 1.430 & 3.078 & .216 & 1 & .642 & 4.180 \\
& AC & 1.0441 \\
& FC & -.300 & .319 & .886 & 1 & .347 & .000
\end{tabular}




\begin{tabular}{|c|c|c|c|c|c|c|}
\hline & B & S.E. & Wald & df & Sig. & $\operatorname{Exp}(B)$ \\
\hline \multirow{3}{*}{$\begin{array}{c}\text { FB } \\
\text { Constant }\end{array}$} & -999 & .0450 & 4.000 & 1 & .040 & 1.2041684538233 .976 \\
\hline & .186 & .125 & 2.194 & 1 & .139 & \\
\hline & 21.245 & 008.090 & .000 & 1 & .998 & \\
\hline
\end{tabular}

Source: Secondary data Prossesed (2020)

\section{Result and Discussion}

Based on the results of calculations on SPSS in table 6, the managerial ownership variable shows a negative coefficient of 1.059 with a significant level (p) of 0.988 , greater than $\alpha=$ $5 \%$. Because the level of significance ( $p$ ) is greater than $\alpha=5 \%$, the 1 st hypothesis is rejected or unsuccessfully supported. This means that it can be concluded that manager ownership has no effect on auditor change. This study failed to prove that manager ownership as measured by the percentage of shares owned by company managers has a significant effect on auditor change. Thus it can be interpreted that the managerial ownership variable has no significant effect on auditor change. Its mean Ownership of company shares is not only owned by the company managerial, but also by the wider community, so that decision making does not only involve one of the owners but involves all the shareholders of the company.

Institutional ownership variable is 1,166 with a significant level (p) of 0.354 , greater than $\alpha$ $=5 \%$. Because the level of significance $(\mathrm{p})$ is greater than $\alpha=5 \%$, the second hypothesis is rejected or unsuccessfully supported. This means that it can be concluded that institutional ownership has no effect on auditor change. This study failed to prove that institutional ownership as measured by the percentage of share ownership by the institution had no significant effect on auditor change. Thus it can be interpreted that the variable institutional ownership has no significant effect on auditor change. Institutional ownership has the ability to control and supervise the performance of company management. High supervision from the institution will minimize fraud and fraud committed by managers and at the same time encourage managers to improve their performance as company managers. The performance of auditors in providing better company audit quality will increase through the supervisory function by the institution, so that companies do not need to change their auditors because the auditors are sufficiently qualified (Sarah, 2018)

The number of independent commissioners and the number of commissioners as a whole shows that the composition of the board of commissioners shows a positive coefficient of 1,430 with a significant level (p) of 0.642 , greater than $\alpha=5 \%$. Because the level of significance (p) is greater than $\alpha=5 \%$, the 3 rd hypothesis is rejected or unsuccessfully supported. This means that it can be concluded that the composition of the board of commissioners has no effect on auditor change. This study failed to prove that the composition of the board of commissioners as measured by the number of independent commissioners has a significant effect on auditor change. This means that the results of the study have not succeeded in proving that companies that have a smaller proportion of independent commissioners will perform auditor change.

The independent board of commissioners who received a new KAP proposal from the audit committee, may consider that even though the old KAP provides an opinion other than unqualified, the old KAP may still be able to behave professionally by holding high its independence, so that the board of commissioners will certainly consider maintaining the old KAP. . Suparlan and Andayani (2010) state that the board of commissioners does not always 
supervise by making a policy to change KAP. In addition, the existence of independent commissioners may occur only to fulfill the formal requirements made by BAPEPAM and are not intended to implement Good Corporate Governance. Audit committee variable shows a negative regression coefficient of 0.300 with a significance level (p) of 0.347 , greater than $\alpha=$ $5 \%$. Because the level of significance (p) is smaller than $\alpha=5 \%$, the 4 th hypothesis is rejected or unsuccessfully supported. This study failed to prove that the number of audit committees had a significant effect on auditor change. Thus it can be interpreted that the audit committee size variable does not have a significant effect on auditor change.

Less supportive of the audit committee size variable in this research is due to the ineffective size of the audit committee in the company. Etika (2015) states that "The number of audit committees does not guarantee the effectiveness of the audit committee's performance in supervising the company's financial performance". The establishment of an audit committee in a company is thought to be based solely on compliance with regulations, where the regulations require companies to have an audit committee. This results in the ineffective existence of the audit committee in monitoring company performance.

The test results in Table 6 show that the audit fee variable shows the coefficient regression of -0.999 with a significance of 0.040 . The results of this study indicate that audit fee has a significant negative effect to auditor switching because it has value significance smaller than 0.05. Based on this, H5 is accepted. In this study the audit fee contract variable has an effect significant negative effect on auditor switching. It can be concluded that if the audit fee is high then it may not necessarily affect the company to do auditor switching, because company assumes that the auditor or KAP used so far have known and understand about the condition of the company (Wea and Murdiawati, 2015). The company thinks that the auditor or KAP has been on duty so far competent in carrying out their duties and are satisfied with the audit results given, so the company is considering do auditor switching even though the fees are offered by the auditor or the KAP tends to be high, the company perceives things is in accordance with the work given by auditors and KAP who are currently on duty. The results of this study are supported by research conducted by Nasir (2018) which states that the audit fee has a negative effect on auditor switching.

The financial bankruptcy variable shows a positive regression coefficient of 0.185 with a significance level (p) of 0.139 greater than $\alpha=5 \%$. Because the level of significance (p) is greater than $\alpha=5 \%$, the 6 th hypothesis is rejected or unsuccessfully supported. This study failed to prove that financial distress has a significant effect on auditor switching. This study failed to prove that financial distress as measured by the company's DER ratio has a significant effect on auditor change. Financial bankruptcy is a liquidity problem that will have severe consequences and cannot be resolved without a change in the size of the company's operations or structure (Aroh et al, 2018). If the company's condition is in financial distress, the company tends not to do auditor switching. This is because auditor changes that occur too often in companies can increase audit fees. When the auditor first audits a client, the first thing to do is to understand the client's business environment and the client's audit risk that will occur, so that it will have an impact on the increase in audit fees. The indicator of financial distress is when the company is unable to fulfill its financial obligations and the company stops its workforce. The results of this study are consistent with research conducted by Martina (2010) and Inawati (2018) which state that financial distress has no effect on auditor switching. The results of this study also support the research results of Astika (2018) and Namira et al. (2019). 


\section{Conclusion and Sugestion}

Based on the results of research and discussion of the influence of manager ownership, institutional ownership, composition of independet commisioner, audit committee, and financial bankruptcy has no effect on auditors change. However udit fee contract has effect to auditor change in bank. Future research may use a sample of other sector companies listed on the Indonesia Stock Exchange (BEI), consider several other variables that are thought to affect auditor switching, Future studies should increase the study period because a longer period is expected to get better results corresponding.

\section{References}

[1] Ashari, D. dan. (2018). Pedoman Praktis Memahami Laporan Keuangan. Managerial Finance. https://doi.org/10.1108/MF-08-2017-0303

[2] Damayanti, S., \& Sudarma, M. (2008). Faktor-Faktor Yang Mempengaruhi Perusahaan Berpindah Kantor Akuntan Publik. Simposium Nasional Akuntansi XI.

[3] Dwijayanti, (2014) Faktor-Faktor Yang Mempengaruhi Auditor Switching Secara Voluntary.

[4] FCGI. (2002). Peranan Dewan Komisaris dan Komite Audit dalam Pelaksanaan Corporate Governance ( Tata Kelola Perusahaan ). Seri Tata Kelola Perusahaan (Corporate Governance).

[5] Ghozali, I. (2018). Aplikasi Analisis Multivariate dengan Program IBM SPSS 25. (Edisi 9). Semarang: Badan Penerbit Universitas Diponegoro.

[6] Harisman. (2017). Pengaruh Ukuran Perusahaan Klien, Kesulitan Keuangan, Ukuran Kap Dan Pergantian Manajemen Terhadap Auditor Switching. JOM Fekon.

[7] Hartadi, B. (2012). Pengaruh Fee Audit, Rotasi Kap, Dan Reputasi Auditor Terhadap Kualitas Audit Di Bursa Efek Indonesia. Ekuitas (Jurnal Ekonomi Dan Keuangan). https://doi.org/10.24034/j25485024.y2012.v16.i1.2315

[8] Ismanto, J., \& Manda, D. L. (2018). Pengaruh Financial Distress, Pergantian Manajemen Dan Ukuran Kap Terhadap Auditor Switching. Media Riset Akuntansi, Auditing \& Informasi. https://doi.org/http://dx.doi.org/10.25105/mraai.v18i2.3069

[9] Karliana, D. R., Suzan, L., \& Yudowati, S. P. (2017). Pengaruh Opini Audit, Reputasi Auditor dan Audit Fee terhadap Auditor Switching (Studi pada Perusahaan Sektor Infrasrtuktur, Utilitas, dan Transportasi yang Terdaftar di Bursa Efek Indonesia Tahun 2010-2015). E-Proceeding of Management.

[10] Linata, Y., \& Sugiarto, B. (2012). Pengaruh Independensi Akuntan Publik, Kualitas Audit, Ketepatan Waktu Pelaporan Serta Mekanisme Corporate Governance Terhadap Integritas Laporan Keuangan Perusahaan LQ45 yang Terdaftar pada BEI Periode 20072010. Akuntansi Keuangan.

[11] Johari, (2015). Pengaruh Corporate Governance Terhadap Voluntary Auditor Switching (Studi Empiris pada Perusahaan Manufaktur, Perdagangan, Jasa, dan Investasi yang Terdaftar di Bursa Efek Indonesia pada Tahun 2009 - 2013).

[12] Peranian, N. A., \& Mimba, P. S. H. (2018). Pengaruh Good Corporate Governance, Financial Distress, dan Return On Equity Pada Voluntary Auditor Switching. E-Jurnal Akuntansi. https://doi.org/10.24843/EJA.2018.v23.i02.p29 
[13] Ramantha, I. W. (2014). Pengaruh Audit Fee , Opini Going Concern , Financial Distress Dan Ukuran Perusahaan Pada. Journal of Accounting.

[14] Resmiyati, A. (2017). Analisis Faktor-Faktor yang Mempengaruhi Auditor Switching (Studi Empiris Pada Perusahaan Manufaktur Yang Mengalami Financial Distress dan Listing di BEI Tahun 2012-2016). Jurnal Al-Buhuts.

[15] Robbitasari, A., \& Wiratmaja, I. (2013). Pengaruh Opini Audit Going Concern, Kepemilikan Institusional Dan Audit Delay Pada Voluntary Auditor Switching. EJurnal Akuntansi.

[16] Salim, A., \& Rahayu, S. (2014). Pengaruh Opini Audit, Ukuran KAP, Pergantian Manajemen, dan Financial Distress terhadap Auditor Switching. E-

[17] Proceeding of Management. https://doi.org/ISSN : 2355-9357

[18] Samanta, N., \& Das, T. (2011). Role of Auditors in Corporate Governance. SSRN Electronic Journal. https://doi.org/10.2139/ssrn.1487050

[19] Sugiyono. (2017). MetodePenelitian Kuantitatif, Kualitatif dan R\&D. Bandung: PT Alfabet. In Sugiyono. (2017). Metode Penelitian Kuantitatif, Kualitatif dan R\&D. Bandung: PT Alfabet. https://doi.org/10.1017/CBO9781107415324.004

[20] Suparlan, \& Andayani, W. (2010). Analisis Empiris Pergantian Kantor Akuntan Publik Setelah Ada Kewajiban Rotasi Audit. Simposium Nasional Akuntansi XIII Purwokerto. https://doi.org/10.1017/CBO9781107415324.004

[21] Wijaya, E., \& Rasmini, N. (2015). Pengaruh Audit Fee, Opini Going Concern, Financial Distress, Ukuran Perusahaan, Ukuran Kap Pada Pergantian Auditor. E-Jurnal Akuntansi. 